\title{
Measuring Tourism Efficiency of European Countries by Using Data Envelopment Analysis
}

\author{
Halenur Soysal-Kurt, MSc. \\ Department of Management Information Systems \\ Osmaniye Korkut Ata University, Turkey
}

doi: 10.19044/esj.2017.v13n10p31 URL:http://dx.doi.org/10.19044/esj.2017.v13n10p31

\begin{abstract}
This study aims to measure relative efficiency of 29 European countries with the data of the year 2013 using input-oriented and constant returns to scale Data Envelopment Analysis and to offer improvement suggestions for the countries found inefficient based on their measured relative efficiency scores. Three input and three output variables are used to assess relative performances of the countries. In this study, tourism expenses, number of employees and number of beds are used as input variables; tourism receipts, tourist arrivals and number of nights spent are used as output variables. As the result of the analysis, 16 countries are found relatively efficient and 13 countries are found relatively inefficient. This study is one of the few publications within the scope of European countries based on data envelopment analysis. Unlike most researches evaluating the efficiency of tourism establishments at the micro level, this paper is thought to contribute to the related literature as it evaluates relative efficiency of the countries at the macro level for tourism industry. Considering the variables used in the analysis, it is expected to give ideas to relatively inefficient European countries on efficiency improvement.
\end{abstract}

Keywords: Data Envelopment Analysis (DEA), Tourism, Efficiency, European countries

\section{Introduction}

It is known that tourism sector is one of the largest and fastest growing industries in the world. Thanks to generation of employment, export revenues, investments and infrastructure developments, tourism sector makes serious contribution to socio-economic process directly and indirectly. According to the report of United Nations World Tourism Organization (UNWTO, 2016), on a global basis, tourism revenues provided by destinations was US\$ 2 billion in 1950; in 2015 it amounted to US\$ 1260 
billion. According to the previous year it increased by $4.4 \%$ in real terms. In addition to tourism revenues, total value of tourism exports provided by international transportation services reached US\$ 1.5 trillion in 2015. International tourist arrivals were 25 million in 1950; in 2015 they reached 1186 million. International tourist arrivals increased by $4.6 \%$ according to the previous year. In 2015, tourism industry contributed 10\% to world gross domestic product (GDP) regarding direct, indirect and induced effects. In terms of employment, it contributed employment one out of every eleven.

Efficiency is the ratio of output to input in general manner and deals with the operational performance of a firm (at micro level) or country (at macro level) (Joppe \& Li, 2016). The processes which produce more outputs per input have bigger efficiency. If the largest possible output per input is provided, optimum efficiency will be achieved. Without using new technologies or making various changes, it is impossible to increase the efficiency (Sherman \& Zhu, 2006).

Efficiency assessment can be divided into two categories as parametric and non-parametric. In parametric methods, production function is preset and changes that may randomly affect production are considered (factor analysis, regression analysis, stochastic frontier approach etc.). In non-parametric methods, analyses are done without presetting production function through linear programming (data envelopment analysis, back error propagation, artificial neural network etc.) (Yi \& Liang, 2015; Oukil et al., 2016).

A tourist destination is a geographical area where tourists enjoy many different experiments and can be divided into several levels as country, region, city, holiday resort. It is possible to analyze the tourist destination like a commercial business. In this case, it aims to produce maximum output managing its inputs effectively (Barros et al., 2011). Physical and human resources of the tourist destination are the inputs of virtual tourist production process. From this point, outputs are affected by factors like tourist arrivals, bed-nights, added-value, employment, customer satisfaction, scientific information, capital resources, infrastructure, etc. (Cracolici et al., 2008; Porter, 1990).

A tourist region may be inefficient for the following reasons (Cracolici et al., 2008):

- The capacity may not be used efficiently because of public regulations (limitations on hotel construction and transportation infrastructure, etc.).

- Global effects may influence outcomes of strategic and operational marketing actions (growing interest in the natural environment, restructuring of the economies around the world, growing complex technology-human resource interface, etc.). 
- $\quad$ Physiography, culture and social impacts may limit operations on the tourist destinations (environmental limits, relief of residents, etc.).

The objective of this study is to measure and compare tourism efficiencies of 29 European countries relatively. Because of this purpose, relative tourism efficiencies are measured with variables accepted in the literature by using the non-parametric method Data Envelopment Analysis (DEA). DEA method is preferred in this paper because of some reasons. One of these, the calculation process is not relatively difficult. The method allows identification and modification of factors affecting efficiency. It evaluates the efficiency of a DMU regarding other DMUs with common factors. It provides optimal weights for each factor and DMU. It permits that poor decision making units (in this paper, countries) are easily detected. Inputoriented CCR model used in this paper focuses on what should be the optimum amount of input corresponding to a certain amount of output. In the analysis, input-oriented CCR model is preferred from the DEA approaches because it may be difficult to make changes in the amount of the outputs of the countries.

The paper consists of five parts. Following the first and introduction part, in the second part literature review made in the field of DEA on tourism, in the third part DEA methodology, in the fourth part efficiency analysis of European countries and its findings, in the last part conclusions are located in the paper.

\section{Literature Review}

There are many studies in the literature that measure efficiency in the tourism industry through DEA. A large part of these studies is carried out at the micro level, assessing the efficiency of the hotels and restaurants. Banker and Morey's study (1986) is one of the early studies which implement DEA in the tourism industry at the micro level. They measure technical and scale efficiencies of 60 restaurants in fast food chain using six input and three output variables. Inputs are expenditures for supplies and materials, expenditures related to labor, advertising expenditures, the age of the store, whether the store is located in an urban or rural area, and whether it has a drive-in window. Outputs are breakfast sales, lunch sales and dinner sales. It is understood from the application that the target output can be obtained by saving the inputs. Johns et al. (1997), firstly use DEA in the hotel sector, compare 15 hotels with each other through DEA using four input and three output variables in 12-month period. The input variables are number of room nights available, total labor hours, total beverage and food costs, and total utilities cost. The output variables are number of room nights sold, total covers served and total beverage revenue. In the conclusion of the study, DEA is determined to be usable for diagnosing and identifying outstanding 
behavior regarding gross profit and measured productivity. Anderson et al. (2000) apply DEA method to 48 hotels in United States using the data of the year 1994. Input variables are the full-time equivalent employees, the number of rooms, total gaming related expenses, total food and beverage expenses, and other expenses. As output variable, total revenue generated from the chosen inputs except employees for the year ending 1994 is used. Using these variables, overall, allocative, technical, pure technical and scale efficiencies of the hotels are measured. As the result of the study, they understand that efficient firms allocate more resources to food and beverage operations, and the less efficient firms spend more on hotel operations and other expenses, and have employees and rooms overmuch. Hwang and Chang (2003) use DEA and Malmquist index to measure managerial performance and efficiency changes between the years 1994-1998 for 45 hotels with the data of the year 1998. Inputs are number of full-time employees, guest rooms, total area of meal department and operating expenses. Outputs are room revenue, food and beverages revenue, and other revenues. In conclusion, they find there are serious differences on efficiency changes derived from customer resources and management styles. Barros and Alves (2004) try to analyze the efficiency of 42 hotels in Portuguese public-owned hotel chain for the period of 1999-2001 by using outputoriented DEA. They rank the hotels regarding their total factor productivity changes. Number of full-time workers, cost of labor, book value of property, operating costs and external costs are used as inputs. As outputs, number of guests and nights spent in the hotel are used. Consequently, they find that while most hotels provide efficient technical change, they do not provide technological change. Barros and Mascarenhas (2005) measure technical and allocative efficiency through DEA with the data of the year 2001 for 43 hotels in Portuguese state-owned chain. Inputs are labor, capital and the number of rooms. Outputs are sales, the number of guests and nights spent. Input prices are price of labor, price of physical capital and price of rooms. In the conclusion of the study, they recognize DEA has several managerial advantages. One of the advantages of using DEA is identifying strategically important pousadas. Another advantage is discovering overall competence and capability of a pousada. Oukil et al. (2016) make a two-stage DEA application for 58 hotels in Sultanate of Oman. Inputs are number of beds and salary of employees. Outputs are annual revenue, number of guests, number of nights and occupancy rate. In the result of the analysis, they find a major part of the hotels in Oman technically inefficient. They determine that location of the most hotels found efficient is at the capital of Muscat, and variables affecting the hotel efficiency mostly are star rating and cultural attractions. 
One of the studies evaluating tourism efficiency at the macro level is the study of Peypoch (2007). Peypoch measures tourism efficiency for French tourism industry with the data set of the years 2000-2003 by Luenberger productivity indicator. The analysis is performed on a nationality-by-nationality basis. Seven countries and one continent are participated in the analysis. He uses the number of tourist bed-nights in hotels and campsites as input variables, and uses tourism receipts based on tourist nationality as output variables. He concludes that compared to the other non-parametric methods like Malmquist productivity index, Luenberger productivity indicator are more useful than the other because of not needing input or output orientation. Cracolici et al. (2008) measure 103 Italian regions' efficiencies with the data set of the year 2001 by constant returns to scale output-oriented DEA and Cobb-Dougles stochastic frontier production function. Inputs are the regional state-owned cultural patrimony and heritage, tourist school graduates and the labor units employed in the tourism sector. Output is bed-nights. According to DEA analysis, only seven regions are found efficient. According to the results of stochastic frontier approach, labor units are found the most effective variable. Compared two methods with each other, the results show a low consistency. Bi et al. (2011) use a two-stage DEA model to measure the efficiency of China's 31 regions. In the first stage, manpower, materials and financial resources are used as inputs. The second stage is the transformation process of tourist facilities and services to economic and social benefits. Inputs used in the first stage are fixed assets and persons engaged in the tourism industry. Outputs are number of star-rated hotels, number of travel agencies and number of other tourism corporations. Inputs used in the second stage are number of excellent tourism cities, number of star-rated hotels, number of travel agencies and number of other tourism corporations. Outputs are the total number of visitors, foreign exchange earnings, tourist income, tax delivery, profits and rate of job growth. In the results of the study, they find that compared to developed countries Chinese regional tourism industry develops at a low level and there are serious efficiency differences between 31 regions. Barros et al. (2011) evaluate the efficiency of 22 French regions for the years 2003-2007 using a two-stage DEA method in their study. In the first stage, they calculate the efficiency scores; in the second stage, they use a bootstrapped truncated regression model. Inputs used to measure the efficiency are accommodation capacity and arrivals; output is nights slept. In the regression model tourism attractors are used. These are monuments, museums, theme parks, beaches, ski resorts and Natural Parks. According to the study's findings, primary factors that affect the efficiency are sea, sun and strategy based on beaches endowment. They believe that developing theme parks, monuments, ski resorts and Natural Parks can enhance tourism attraction and improve the 
efficiencies. Assaf (2012) measures and compares the efficiencies of leader tour operators and hotel firms in 12 Asian Pacific countries for the years 2007-2009. He uses a combination of stochastic frontier in Bayes framework and DEA as the method. Inputs for the hotels are number of rooms, number of full time equivalent employees and other operational costs. For the tour operators, inputs are the same as the hotels; in addition to those the number of rooms by the number of outlets is used. Total revenues are used as output for both hotels and tour operators. In the results, Australia has the highest efficiency in hotel and tour operator industry. The author believes that the factors affecting that finding are outstanding air freight and tourism infrastructure, and serious tourism appeal. Hadad et al. (2012) examine tourism efficiency of 34 developed and 71 developing countries in two parts using DEA based on super-efficiency with the data of the year 2008. Inputs are number of employees, number of rooms, natural resources and cultural resources. Outputs are number of tourists and expenditure per tourist. As the result of the study, in developed countries Luxembourg, France, Ireland and Singapore; in developing countries Ukraine, Bosnia, Brunei, Bahrain, Puerto Rico, Hungary and Croatia are found efficient. It indicates that globalization and accessibility play an important role in the efficiency of the tourism industry. Assaf and Barros (2013) measure and compare performances of hotel industries of countries worldwide with the stochastic frontier semiparametric approach. 26 from 37 countries are analyzed for the first time in the literature. Using the data set of the years 2006-2008, they analyze 519 hotels with three input and three output variables. Inputs are number of outlets, number of full-time equivalent employees and other operational costs. Outputs are operational revenue, annual occupancy rate and market share. According to the findings, they find the most efficient countries in hotel industry as Spain, France, Germany, the USA, United Kingdom (UK), United Arab Emirates (UAE) and Turkey. Kosmaczewska (2014) evaluates tourism interest in terms of efficiency for the years 2007-2009. She analyzes 27 European Union (EU) countries through CCR, BCC and NIRS (nonincreasing returns to scale) models. As input, the arrivals in tourist accommodation establishments are used; as outputs, collective tourist accommodation establishments and GDP per inhabitant are used in the analyses. Consequently, she determines that the efficiency of richer and poorer countries resemble each other. In Atan and Arslantürk (2015)'s study, efficiency analyses of 91 worldwide countries are performed for the years 2006-2010 through CCR and BCC models. Inputs are number of arrivals, total activity, tourism expenses, tourism expenses for passenger transportation needs and tourism expenses for travel needs. Outputs are tourism revenues, tourism revenues for passenger transportation needs and tourism revenues for travel needs. As the result of the study, according to 
CCR model 65 countries, BCC model 67 countries are found efficient. The findings of both models resemble each other.

In recent years, a considerable amount of study has been done on efficiency and productivity analysis in the tourism literature. Both its economic contributions and increasing competition in the global tourism market have promoted the number of studies on tourism efficiency. However, the majority of the tourism efficiency studies is bounded by travel agents, hospitality industry and food \& beverage facilities (micro-level) (Hadad et al., 2012). When it is considered that efficiency measurement is usually carried out for commercial businesses, countries in this paper are considered as commercial businesses aiming to produce maximum output managing their inputs effectively. The efficiency of the tourism industry at the macro level has been discussed in few studies. Unlike most studies evaluating the efficiency of tourism establishments, the study is thought to contribute to the related literature as it evaluates relative efficiencies of the countries at the macro level for tourism industry. In addition, it is one of the few publications within the scope of European countries based on data envelopment analysis.

\section{Data Envelopment Analysis}

DEA is firstly developed by Charnes, Cooper and Rhodes (1978) (CCR) and is a non-parametric method that is used to assess the relative efficiency of decision making units (DMUs) in the situations where multiple inputs and outputs are available (Despotis \& Simirlis, 2002). DEA determines the efficiency of DMUs with common inputs and outputs through the ratio of weighted outputs to weighted inputs of each DMU. DMUs are compared with each other by constituting linear programming model (LP). The efficient frontier consisting of the best observations is specified so that the efficiencies of all DMUs are calculated by the distance from this frontier. DMUs on the efficient frontier are relatively efficient; those outside the frontier are relatively inefficient. Reference sets consisting of the efficient DMUs are determined for the inefficient DMUs, thus suggestions providing to be efficient for the inefficient DMUs can be given.

DEA is firstly used to improve planning and controlling of the activities of public institutions by Charnes et al. (1978). Afterwards, it is used to measure the relative efficiency in many areas and institutions as hospitals, schools, factories, government business enterprises, service industry, etc. One of the areas DEA used in is tourism industry that is discussed in this paper.

Figure 1 shows the classification of DEA approaches by returns to scale and orientation. DEA models are divided into two categories according to scale as constant returns (CRS) and variable returns (VRS). CRS assumes 
that there is no substantial relationship between scale and efficiency of the DMU. If inputs change in a proportion, outputs change in that proportion. In VRS, there are increasing, decreasing and constant returns to scale for production process. According to the orientation, DEA differs depending on input-oriented, output-oriented and nonoriented. In input-oriented models, it is aimed to minimize the amount of inputs to produce predetermined outputs. In output-oriented models, it is aimed to produce maximum output using predetermined inputs. CCR (Charnes, Cooper \& Rhodes, 1978) is the first DEA model that calculates total efficiency based on constant returns to scale. In BCC (Banker, Charnes \& Cooper, 1984) model, there is no obligation to be constant returns to scale. BCC model investigates local returns to scale under the assumption of VRS (Charnes et al., 1994). Each DMU must provide both technical and scale efficiency to be CCR-efficient, while it is sufficient to provide only technical efficiency to be BCC-efficient (Bowlin, 1998). Because input-oriented constant returns to scale CCR model is used in this study, only this model is discussed in the following section.

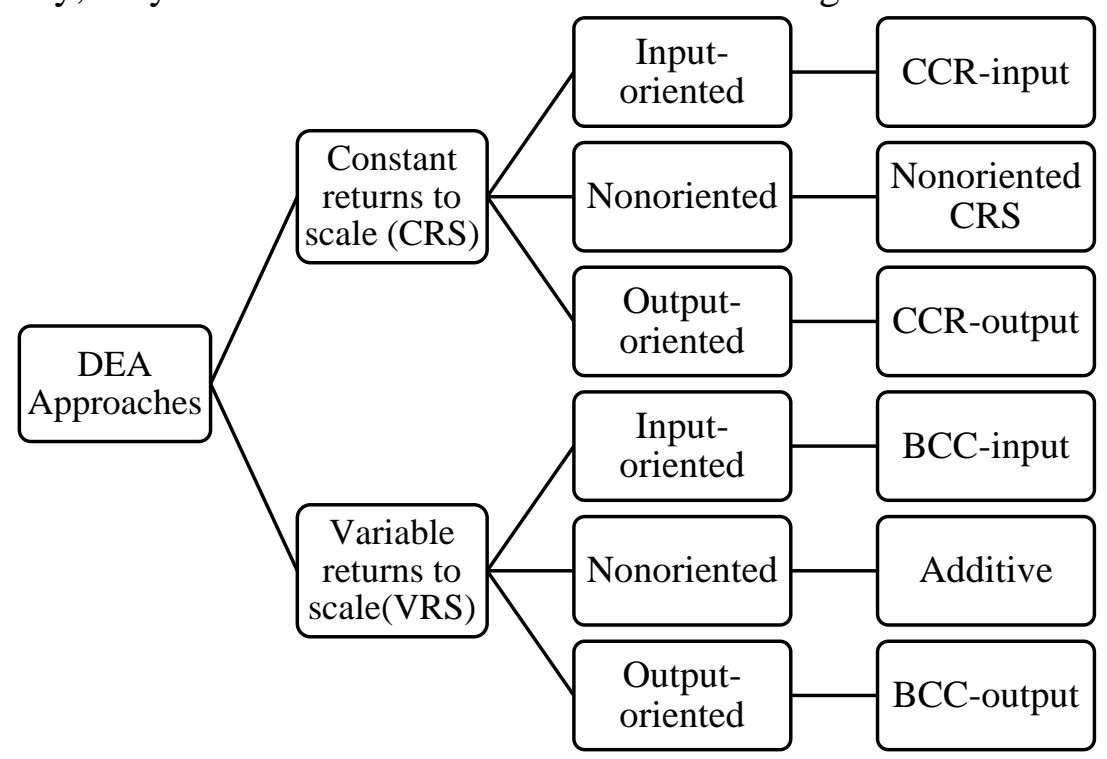

Figure 1. Classification by returns to scale and orientation (Ali, 1994)

\section{Input-oriented CCR model}

Input-oriented CCR model focuses on what should be the optimum amount of input corresponding to a certain amount of output. In CCR model, the efficiencies of DMUs are provided by the ratio of virtual outputs to virtual inputs.

Assume that $n$ is the number of DMUs, $s$ is the number of outputs and $m$ is the number of inputs; CCR model for $\mathrm{DMU}_{\mathrm{o}}$ is as follows (Charnes et al., 1978): 
subject to:

$$
\operatorname{maxh}_{o}=\frac{\sum_{r=1}^{s} u_{r} y_{r o}}{\sum_{i=1}^{m} v_{i} x_{i o}}
$$

$$
\begin{aligned}
& \frac{\sum_{r=1}^{s} u_{r} y_{r j}}{\sum_{i=1}^{m} v_{i} x_{i j}} \leq 1 \quad j=1, \ldots, n \\
& v_{i}, u_{r} \geq 0 ; \quad i=1, \ldots, m ; \quad r=1, \ldots, s
\end{aligned}
$$

Because the model above is fractional programming form, for facilitating the solution it is transformed into linear programming form. The results of both models are the same. CCR model in LP form for $\mathrm{DMU}_{\mathrm{o}}$ is as follows (Cooper et al., 2006):

subject to:

$$
\max \theta=\sum_{r=1}^{s} u_{r} y_{r o}
$$

$$
\begin{aligned}
& \sum_{i=1}^{m} v_{i} x_{i o}=1 \\
& \sum_{r=1}^{s} u_{r} y_{r j}-\sum_{i=1}^{m} v_{i} x_{i j} \leq 0 \quad j=1, \ldots, n \\
& v_{i}, u_{r} \geq 0 ;
\end{aligned}
$$

In the model above, by generating maximization problems for all DMUs, efficiency scores of each DMU are obtained. To assess the efficiencies correctly, the number of DMUs must be greater than the sum of the number of inputs and outputs three times (Raab \& Lichty, 2002). $v_{i}$ and $u_{r}$ respectively represent the weights of each input and the weights of each output (the relative importance degrees). The equality constraint represents the sum of the virtual inputs of $\mathrm{DMU}_{0}$. Inequality constraint states that the sum of the weighted outputs cannot be greater than the sum of the weighted inputs for each DMU. The inequalities as many as the number of DMUs are added on the LP model. The objective function represents the virtual outputs of $\mathrm{DMU}_{0}$. If the optimum value of the objective function $\left(\theta^{*}\right)$ is equal to 1 , $\mathrm{DMU}_{\mathrm{o}}$ will be efficient. If the value $\theta^{*}$ is smaller than $1, \mathrm{DMU}_{0}$ will be inefficient relatively.

The dual form of CCR model for $\mathrm{DMU}_{\mathrm{o}}$ is as follows (Banker et al., 2004):

$$
\text { minimize } \theta-\varepsilon\left(\sum_{i=1}^{m} s_{i}^{-}+\sum_{r=1}^{s} s_{r}^{+}\right)
$$

subject to: 


$$
\begin{aligned}
& 0=\theta x_{i o}-\sum_{j=1}^{n} x_{i j} \lambda_{j}-s_{i}^{-}, \\
& y_{r o}=\sum_{j=1}^{n} y_{r j} \lambda_{j}-s_{r}^{+}, \\
& 0 \leq \lambda_{j}, s_{i}^{-}, s_{r}^{+} \quad \forall i, j, r .
\end{aligned}
$$

The dual model with adding slack variables contains information for inefficient DMUs about what should be done to become efficient.

$\theta$ is a value between zero and one. It determines how much the input $x_{i o}$ should be reduced to $\theta x_{0}$ radially to get $\mathrm{DMU}_{\mathrm{o}}$ to the efficient frontier (Kulshreshtha \& Parikh, 2002; Cooper et al., 2006).

The values $\lambda_{j}$ are the density values of the elements in the reference sets that provide $\mathrm{DMU}_{\mathrm{o}}$ to be efficient.

The value $s_{i}^{-}$(input excesses) is the slack input value belonging to $i$. input of $\mathrm{DMU}_{0}$. The value $s_{r}^{+}$(output shortfalls) is the slack output value belonging to $r$. output of $\mathrm{DMU}_{0}$.

According to dual model, if the weighted inputs of relatively inefficient $\mathrm{DMU}_{\mathrm{o}}$ are converted to $\left(\theta x_{i o}-s_{i}^{-}\right)$and the weighted outputs of relatively inefficient $\mathrm{DMU}_{\mathrm{o}}$ are converted to $\left(y_{r o}+s_{r}^{+}\right)$, $\mathrm{DMU}_{\mathrm{o}}$ will be efficient.

To determine the possible input excesses and output shortfalls, twostage LP model is solved (Cooper et al., 2007):

\section{Stage I}

The dual form of the model is solved and then the value $\theta^{*}$ is found. The value $\theta^{*}$ is the same as the efficiency value calculated in the primal linear model. The value $\theta^{*}$ obtained will be used in Stage II.

\section{Stage II}

Using the value $\theta^{*}$, the following model is solved:

$$
\max _{\lambda, s^{-}, s^{+}} w=e s^{-}+e s^{+}
$$$$
s^{-}=\theta^{*} x_{o}-X \lambda
$$

subject to:

$s^{+}=Y \lambda-y_{o}$

$$
0 \leq \lambda_{j}, s_{i}^{-}, s_{r}^{+}
$$

$$
e=(1, \ldots, 1) \text { a vector whose elements equal to } 1 \text {. }
$$

$$
e s^{-}=\sum_{i=1}^{m} s_{i}^{-} ; e s^{+}=\sum_{r=1}^{s} s_{r}^{+}
$$

The purpose of Stage II is to find a solution which makes the sum of the input excesses and output shortfalls maximum maintaining $\theta=\theta^{*}$. In 
order to be CCR-efficient with optimal solution values $\left(\theta^{*}, \lambda^{*}, s^{-*}, s^{+*}\right)$, $\mathrm{DMU}_{\mathrm{o}}$ must satisfy following two criteria (Cooper et al., 2007):

$$
\text { I. } \theta^{*}=1
$$

II. All slacks $\left(s_{i}^{-*}, s_{r}^{+*}\right)$ are equal to zero.

But in some cases, it can be seen that only the first constraint is satisfied. In this situation, $\mathrm{DMU}_{\mathrm{o}}$ is characterized as “weak efficient”.

\section{Analyses and Findings}

In this study, DEA method is applied to 29 European countries with high income and upper-middle income using variables compiled from the studies in the literature (Hwang \& Chang, 2003; Oukil et al., 2016; Hadad et al., 2012; Assaf, 2012). The application is performed using constant returns to scale (CRS) and input-oriented (CCR) DEA through MDEAP 2 software developed by Michel Deslierres. In the analysis, three input and three output variables thought to affect the tourism efficiency and used commonly in the literature are used. In order for the analysis to produce more reasonable results, countries with similar income levels are preferred for the analysis. The grouping of countries by income levels is based on the order of The World Bank. Due to limited data availability, only European countries are participated in the analysis.

\section{Inputs}

Number of employees: Employed persons by full-time/part-time activity in the tourism sector.

Tourism expenses: The money spent for tourism activities.

Number of beds: Number of beds in tourist accommodation establishments.

\section{Outputs}

Tourist arrivals: The number of the tourist coming from other countries. (overnight visitors).

Tourism receipts: The money spent by international tourists.

Number of nights spent: 1 night or over nights spent in tourist accommodation establishments.

Descriptive statistics of variables used to measure the efficiency of European countries are given in Table 1. Data set of the variables is accessed from Eurostat, The World Bank and World Economic Forum. As it is seen from the standard deviation values in Table 1, data is spread over a wide range. 
Table 1. Descriptive statistics of variables for European countries

\begin{tabular}{|c|c|c|c|c|}
\hline Variables & Minimum & Maximum & Mean & Std. Deviation \\
\hline $\begin{array}{c}\text { Number of employees } \\
\text { (thousand) }\end{array}$ & 175,9 & $39.531,4$ & $8.299,121$ & $10.545,1351$ \\
\hline $\begin{array}{c}\text { Tourism expenses } \\
\text { (million \$) }\end{array}$ & 384 & 91.366 & $12.507,97$ & $19.841,258$ \\
\hline $\begin{array}{c}\text { Number of beds } \\
\text { (thousand) }\end{array}$ & 38,40 & $5.049,73$ & $1.074,2069$ & $1.484,45145$ \\
\hline Arrivals (thousand) & 944 & 84.726 & $16.156,24$ & $19.910,034$ \\
\hline $\begin{array}{c}\text { Tourism receipts } \\
\text { (million \$) }\end{array}$ & 1.190 & 66.049 & $17.196,34$ & $19.790,611$ \\
\hline $\begin{array}{c}\text { Number of nights spent } \\
\text { (thousand) }\end{array}$ & $3.079,21$ & $1.312 .992,49$ & $218.993,5648$ & $353.920,05784$ \\
\hline
\end{tabular}

In Table 2, European countries are numbered from 1 to 29 to identify reference countries which will be discussed in later section. The findings of input-oriented (CCR) and constant returns to scale (CRS) DEA model are given in Table 2.

According to the findings, 16 countries are found efficient; 13 countries are found inefficient. Efficient countries whose efficiency scores are equal to 1 are Cyprus, Croatia, Estonia, Finland, France, Greece, Hungary, Ireland, Latvia, Luxembourg, Malta, Poland, Portugal, Spain, Switzerland and Turkey. Inefficient countries whose efficiency scores are found less than 1 are Austria, Belgium, Bulgaria, Czech Republic, Denmark, Germany, Italy, Lithuania, Netherlands, Romania, Slovak Republic, Slovenia and United Kingdom. Regarding variables used, the countries with the lowest efficiency score are Italy with 0,455 efficiency score, Netherlands with 0,616, Belgium with 0,651 and United Kingdom with 0,66. It should be considered that the efficiency scores calculated in DEA are relative measures.

Table 2. Efficiency scores of European countries for the year 2013

\begin{tabular}{|c|c|c|}
\hline No & Countries & Efficiency scores \\
\hline 1 & Austria & 0,813 \\
\hline 2 & Belgium & 0,651 \\
\hline 3 & Bulgaria & 0,792 \\
\hline 4 & Cyprus & 1,000 \\
\hline 5 & Croatia & 1,000 \\
\hline 6 & Czech Republic & 0,783 \\
\hline 7 & Denmark & 0,848 \\
\hline 8 & Estonia & 1,000 \\
\hline 9 & Finland & 1,000 \\
\hline 10 & France & 1,000 \\
\hline 11 & Germany & 0,760 \\
\hline 12 & Greece & 1,000 \\
\hline 13 & Hungary & 1,000 \\
\hline 14 & Italy & 0,455 \\
\hline 15 & Ireland & 1,000 \\
\hline 16 & Latvia & 1,000 \\
\hline 17 & Lithuania & 0,879 \\
\hline
\end{tabular}




\begin{tabular}{|l|c|c|}
\hline 18 & Luxembourg & 1,000 \\
\hline 19 & Malta & 1,000 \\
\hline 20 & Netherlands & 0,616 \\
\hline 21 & Poland & 1,000 \\
\hline 22 & Portugal & 1,000 \\
\hline 23 & Romania & 0,962 \\
\hline 24 & Slovak Republic & 0,828 \\
\hline 25 & Slovenia & 0,975 \\
\hline 26 & Spain & 1,000 \\
\hline 27 & Switzerland & 1,000 \\
\hline 28 & Turkey & 1,000 \\
\hline 29 & United Kingdom & 0,660 \\
\hline
\end{tabular}

To interpret the findings in more detail, let us take Belgium, which is inefficient, and Switzerland, which is efficient. One reason for Belgium's inefficiency relative to Switzerland may be the fact that the number of nights spent per bed in Switzerland is about 503,7, while in Belgium it is about 258,8. Furthermore, tourist arrivals per bed in Switzerland is 36,4, while in Belgium 20,5. These mean that Switzerland uses its bed capacity more than Belgium. In addition, the number of tourist arrivals per employee in Belgium is lower. Because the ratio is about 2,01 in Switzerland, it is about 1,68 in Belgium. Another example is United Kingdom, which is inefficient. The number of nights spent per bed is about 220,9 in United Kingdom. Similarly, the ratio of tourist arrivals per bed is 7,8 in United Kingdom. Both imply that United Kingdom cannot use its bed capacity as well as Switzerland.

Table 3 . Reference sets and $\lambda$ density values of European countries according to CCR model

\begin{tabular}{|c|c|c|c|c|c|c|c|c|c|c|}
\hline \multirow{2}{*}{$\begin{array}{c}\text { Country } \\
\text { no }\end{array}$} & \multicolumn{10}{|c|}{ Reference countries and $\lambda$ density values } \\
\hline & No & $\lambda$ & No & $\lambda$ & No & $\lambda$ & No & $\lambda$ & No & $\lambda$ \\
\hline 1 & 4 & 3,10869 & 5 & 0,0114 & 10 & 0,0167 & 19 & 9,98518 & & \\
\hline 2 & 9 & 0,14296 & 15 & 0,41309 & 18 & 0,34945 & 27 & \begin{tabular}{|l|}
0,39034 \\
\end{tabular} & & \\
\hline 3 & 5 & 0,08693 & 19 & 2,04323 & 28 & 0,07176 & & & & \\
\hline 4 & 4 & 1,000 & & & & & & & & \\
\hline 5 & 5 & 1,000 & & & & & & & & \\
\hline 6 & 9 & 0,11111 & 21 & 0,06912 & 26 & 0,14683 & & & & \\
\hline 7 & 4 & 2,32512 & 9 & 0,41505 & 15 & 0,21843 & & & & \\
\hline 8 & 8 & 1,000 & & & & & & & & \\
\hline 9 & 9 & 1,000 & & & & & & & & \\
\hline 10 & 10 & 1,000 & & & & & & & & \\
\hline 11 & 9 & 9,06177 & 27 & 0,91642 & & & & & & \\
\hline 12 & 12 & 1,000 & & & & & & & & \\
\hline 13 & 13 & 1,000 & & & & & & & & \\
\hline 14 & 5 & 0,04979 & 13 & 0,00083 & 19 & 12,2053 & 26 & 0,45896 & & \\
\hline 15 & 15 & 1,000 & & & & & & & & \\
\hline 16 & 16 & 1,000 & & & & & & & & \\
\hline 17 & 8 & 0,35955 & 13 & 0,00482 & 21 & 0,05458 & 28 & \begin{tabular}{|l|}
0,00172 \\
\end{tabular} & & \\
\hline 18 & 18 & 1,000 & & & & & & & & \\
\hline 19 & 19 & 1,000 & & & & & & & & \\
\hline 20 & 4 & 3,31776 & 9 & 1,51475 & 10 & 0,00668 & & & & \\
\hline 21 & 21 & 1,000 & & & & & & & & \\
\hline 22 & 22 & 1,000 & & & & & & & & \\
\hline
\end{tabular}




\begin{tabular}{|c|c|c|c|c|c|c|c|c|c|c|}
\hline 23 & 21 & 0,10707 & 26 & 0,06358 & & & & & & \\
\hline 24 & 8 & 1,50457 & 13 & 0,12338 & 21 & 0,0227 & 28 & 0,00626 & & \\
\hline 25 & 4 & 0,23432 & 16 & 0,17319 & 22 & 0,07169 & 26 & 0,00998 & 28 & 0,00605 \\
\hline 26 & 26 & 1,000 & & & & & & & & \\
\hline 27 & 27 & 1,000 & & & & & & & & \\
\hline 28 & 28 & 1,000 & & & & & & & & \\
\hline 29 & 4 & 2,54309 & 9 & 4,6719 & 22 & 0,61776 & 26 & 0,2705 & & \\
\hline
\end{tabular}

Reference sets determined to give suggestions which will provide to be efficient for the inefficient countries and $\lambda$ density values are given in Table 3. According to the reference sets given in the table, the most referenced countries are Finland (6 times), Cyprus (5 times), Spain (5 times), Turkey (4 times) and Poland (4 times). Thanks to the countries in the reference set of an inefficient country and $\lambda$ density values, input quantities to achieve to be efficient are calculated. For relatively inefficient countries, actual input values, target input values calculated according to CCR model and potential improvement rates for the input variables are respectively given in Table 4 and Table 5.

Table 4. Actual and target input values of European countries according to input-oriented CCR model

\begin{tabular}{|c|c|c|c|c|c|c|c|c|}
\hline \multirow[b]{2}{*}{ No } & \multirow[b]{2}{*}{ Countries } & \multirow[b]{2}{*}{$\begin{array}{c}\text { Efficiency } \\
\text { scores }\end{array}$} & \multicolumn{3}{|c|}{ Actual Input Values } & \multicolumn{3}{|c|}{ Target Input Values } \\
\hline & & & $\begin{array}{l}\text { Number of } \\
\text { employees } \\
\text { (thousand) }\end{array}$ & \begin{tabular}{|c|} 
Tourism \\
expenses \\
(million \\
$\$$ )
\end{tabular} & $\begin{array}{l}\text { Number of } \\
\text { beds } \\
\text { (thousand) }\end{array}$ & $\begin{array}{l}\text { Number of } \\
\text { employees } \\
\text { (thousand) }\end{array}$ & $\begin{array}{c}\text { Tourism } \\
\text { expenses } \\
\text { (million \$) }\end{array}$ & $\begin{array}{c}\text { Number of } \\
\text { beds } \\
\text { (thousand) }\end{array}$ \\
\hline$\frac{1}{1}$ & Aust & 13 & 7 & 10.277 & 981,07 & 99,08 & 0,1 & 8,08 \\
\hline 2 & Belgit & 0, & $4.530,3$ & 21.876 & 372,87 & $2.952,9$ & \begin{tabular}{|l|}
$10.913,5$ \\
\end{tabular} & 243,04 \\
\hline 3 & Bulga & 2 & $2.934,9$ & 1.527 & 302,43 & $2.323,28$ & $1.208,78$ & 239,4 \\
\hline 4 & Сур & 0 & 1 & 1.222 & 87,14 & 65,1 & 1.222 & 87,14 \\
\hline 5 & $\mathrm{CrC}$ & & & 3 & 001 & & & 867,11 \\
\hline 6 & $\begin{array}{c}\text { Czech } \\
\text { Republic }\end{array}$ & 0,783 & $4.937,1$ & 4.595 & 740,67 & $3.865,56$ & $3.597,71$ & 579,92 \\
\hline 7 & Denr & 848 & $2.687,6$ & 10.132 & 417,59 & $.279,45$ & $6.392,18$ & 354,17 \\
\hline 8 & Estonia & 0 & ,3 & 995 & 55,48 & 1,3 & 5 & 48 \\
\hline 9 & $\mathrm{~F}$ & 0 & 456,7 & 5.292 & 254,11 & 456,7 & 5.292 & 254,11 \\
\hline 10 & Frc & 0 & 63,6 & 42.907 & $5.049,73$ & $25.763,6$ & 42.907 & $5.049,73$ \\
\hline 11 & Germany & 760 & $39.531,4$ & 91.366 & $3.326,82$ & $26.349,94$ & $62.666,23$ & $2.528,58$ \\
\hline 12 & Greece & 000 & $3.513,2$ & 2.437 & $1.207,39$ & $3.513,2$ & 2.437 & $1.207,39$ \\
\hline 13 & Hungary & 000 & 892,8 & 1.908 & 422,04 & $3.892,8$ & 1.908 & 422,04 \\
\hline 14 & ly & 455 & $22.190,5$ & 26.972 & 4728,18 & $10.092,12$ & $12.266,73$ & $2.150,35$ \\
\hline 15 & Ireland & 000 & $1.881,2$ & 6.201 & 211,03 & $1.881,2$ & 6.201 & 211,03 \\
\hline 16 & $\overline{\mathrm{La}}$ & 0 &, 9 & 715 & 38 & 3,9 & 715 & 38,4 \\
\hline 17 & Lithuania & 79 & $1.292,8$ & 966 & 69,29 & $1.135,9$ & 848,76 & 60,88 \\
\hline 18 & Luxembourg & 00 & 238,7 & 3.804 & 66,75 & 238,7 & 3.804 & 66,75 \\
\hline 19 & Malta & 0 & 75,9 & 384 & 43,36 & 175,9 & 384 & 43,36 \\
\hline 20 & Netherlands & 616 & 285,2 & 20.056 & $1.404,85$ & $5.104,72$ & $12.357,01$ & 707,76 \\
\hline 21 & Poland & 00 & $15.568,0$ & 8.675 & 679,45 & $15.568,0$ & 8.675 & 679,45 \\
\hline 22 & Portugal & 0 & 429,4 & 4.143 & 491 & $4.429,4$ & 4.143 & 491,1 \\
\hline 23 & Ror & 62 & $8.549,1$ & 2.056 & 303,24 & $2.766,66$ & \begin{tabular}{|l|}
$1.978,09$ \\
\end{tabular} & 291,75 \\
\hline 24 & $\begin{array}{c}\text { Slovak } \\
\text { Republic }\end{array}$ & 28 & 2 & 2. & 31 & 1.9 & $1.959,55$ & 55 \\
\hline 25 & Slovenia & $0,9 / 5$ & 900,9 & 920 & 105,56 & 883,51 & 900,19 & 102,95 \\
\hline
\end{tabular}




\begin{tabular}{|l|c|c|c|c|c|c|c|c|}
\hline 26 & Spain & 1,000 & $17.139,0$ & 16.414 & $3.437,36$ & $17.139,0$ & 16.414 & $3.437,36$ \\
\hline 27 & Switzerland & 1,000 & $4.460,7$ & 16.053 & 246,49 & $4.460,7$ & 16.053 & 246,49 \\
\hline 28 & Turkey & 1,000 & $25.519,8$ & 4.817 & $1.051,16$ & $25.519,8$ & 4.817 & $1.051,16$ \\
\hline 29 & UK & 0,660 & $29.952,5$ & 52.748 & $4.001,02$ & $19.778,31$ & $34.830,69$ & $2.641,96$ \\
\hline
\end{tabular}

For example, considering the inefficient country Denmark with 0,848 efficiency score, its reference countries are found as Cyprus with $\lambda_{4}=2,32512$ density value, Finland with $\lambda_{9}=0,41505$, Ireland with $\lambda_{15}=0,21843$. The calculation of Denmark's target values of input variables to become efficient is as follows:

$$
\begin{gathered}
\mathrm{X}_{\text {Denmark }}=\left(\mathrm{X}_{1}, \mathrm{X}_{2}, \mathrm{X}_{3}\right)=\{(365,1 ; 1.222 ; 87,14) \times 2,32512+(2.456,7 ; \\
5.292 ; 254,11) \times 0,41505+(1.881,2 ; 6.201 ; 211,03) \times 0,21843 \\
=\{(2.279,45 ; 6.392,2 ; 354,17)\}
\end{gathered}
$$

Potential improvement rates for the inputs in Table 5 are calculated according to the formula $\left(\frac{\text { Target value-Actual value }}{\text { Actual value }} * 100\right)$.

Table 5. Potential improvement rates of European countries according to input-oriented

CCR model

\begin{tabular}{|c|c|c|c|c|}
\hline \multirow{2}{*}{ No } & \multirow{2}{*}{ Countries } & \multicolumn{3}{|c|}{ Potential Improvement Rates (\%) } \\
\cline { 3 - 5 } & & $\begin{array}{c}\text { Number of } \\
\text { employees }\end{array}$ & Tourism expenses & Number of beds \\
\hline 1 & Austria & $-18,65 \%$ & $-18,65 \%$ & $-18,65 \%$ \\
\hline 2 & Belgium & $-34,82 \%$ & $-50,11 \%$ & $-34,82 \%$ \\
\hline 3 & Bulgaria & $-20,84 \%$ & $-20,84 \%$ & $-20,84 \%$ \\
\hline 4 & Cyprus & $0 \%$ & $0 \%$ & $0 \%$ \\
\hline 5 & Croatia & $0 \%$ & $0 \%$ & $0 \%$ \\
\hline 6 & Czech Republic & $-21,7 \%$ & $-21,7 \%$ & $-21,7 \%$ \\
\hline 7 & Denmark & $-15,19 \%$ & $-36,91 \%$ & $-15,19 \%$ \\
\hline 8 & Estonia & $0 \%$ & $0 \%$ & $0 \%$ \\
\hline 9 & Finland & $0 \%$ & $0 \%$ & $0 \%$ \\
\hline 10 & France & $0 \%$ & $0 \%$ & $0 \%$ \\
\hline 11 & Germany & $-33,34 \%$ & $-31,41 \%$ & $-23,99 \%$ \\
\hline 12 & Greece & $0 \%$ & $0 \%$ & $0 \%$ \\
\hline 13 & Hungary & $0 \%$ & $0 \%$ & $0 \%$ \\
\hline 14 & Italy & $-54,52 \%$ & $-54,52 \%$ & $-54,52 \%$ \\
\hline 15 & Ireland & $0 \%$ & $0 \%$ & $0 \%$ \\
\hline 16 & Latvia & $0 \%$ & $0 \%$ & $0 \%$ \\
\hline 17 & Lithuania & $-12,14 \%$ & $-12,14 \%$ & $-12,14 \%$ \\
\hline 18 & Luxembourg & $0 \%$ & $0 \%$ & $0 \%$ \\
\hline 19 & Malta & $0 \%$ & $0 \%$ & $0 \%$ \\
\hline 20 & Netherlands & $-38,39 \%$ & $-38,39 \%$ & $-49,62 \%$ \\
\hline 21 & Poland & $0 \%$ & $0 \%$ & $0 \%$ \\
\hline 22 & Portugal & $0 \%$ & $0 \%$ & $0 \%$ \\
\hline 23 & Romania & $-67,64 \%$ & $-3,79 \%$ & $-3,79 \%$ \\
\hline 24 & Slovak Republic & $-17,21 \%$ & $-17,21 \%$ & $-17,21 \%$ \\
\hline 25 & Slovenia & $-2,47 \%$ & $-2,47 \%$ & $-2,47 \%$ \\
\hline 26 & Spain & $0 \%$ & $0 \%$ & $0 \%$ \\
\hline 27 & Switzerland & $0 \%$ & $0 \%$ & $0 \%$ \\
\hline 28 & Turkey & $0 \%$ & $0 \%$ & $0 \%$ \\
\hline 29 & United Kingdom & $-33,97 \%$ & $-33,97 \%$ & $-33,97 \%$ \\
\hline & & & & \\
\hline & & & $0 \%$ & $\%$ \\
\hline
\end{tabular}


For example, according to Table 5, some improvements are required to make Denmark efficient. To make Denmark efficient, number of employees (thousand) should be reduced from 2.687,6 to 2.279,45; tourism expenses (million \$) should be reduced from 10.132 to 6.392,2; number of beds (thousand) should be reduced from 417,59 to 354,17. Thus, it can be applied -15,19\% improvement to number of employees, -36,91\% improvement to tourism expenses and -15,19\% improvement to number of beds. Because the analyses are for input-oriented CCR model, there will be no change in outputs.

\section{Conclusion}

In many studies in the literature, tourism efficiency analyses have been done in subcategories of tourism industry like hospitality industry, travel agencies, and restaurants. In some of the studies, economic efficiency assessment has been also considered. This study evaluates tourism efficiency at the macro level (based on countries) using basic characteristics (number of employees, tourism expenses, number of beds, tourism receipts, tourist arrivals, number of nights spent) that affect the efficiency of tourism industry. For this purpose, tourism efficiency of 29 European countries with high income and upper-middle income is tried to be analyzed. In the analysis, CCR-DEA method is used with the data set of the year 2013. According to the findings of the analysis, 16 countries are identified efficient; 13 countries are identified inefficient. The countries identified relatively efficient are Cyprus, Croatia, Estonia, Finland, France, Greece, Hungary, Ireland, Latvia, Luxembourg, Malta, Poland, Portugal, Spain, Switzerland and Turkey. Relatively inefficient countries are Austria, Belgium, Bulgaria, Czech Republic, Denmark, Germany, Italy, Lithuania, Netherlands, Romania, Slovak Republic, Slovenia and United Kingdom. The countries with the lowest efficiency scores are found as Italy, Netherlands, Belgium and United Kingdom. It should be considered that the efficiency scores calculated in DEA are relative measures and there are other controllable and uncontrollable factors (globalization, physical capitals, cultural and natural resources, accessibility, environmental sustainability, safety, etc.) affecting the efficiency. It is necessary to use various indicators for more detailed evaluation of the efficient use of resources. From this point, these findings do not give the countries definite results about their tourism efficiency, give only a preliminary idea on the balance of inputs/outputs according to the given variables. This paper may be suggestive in terms of resource allocation and long-term decisions of local governments and major tourism companies.

Due to the limitation of data availability, the number of countries and variables used in the analysis are limited. For a more comprehensive 
analysis, variables affecting tourism efficiency (natural and cultural resources, etc.) can be enhanced. In this study, when the relative efficiencies of European countries are analyzed through DEA method, only inputoriented CCR model is used. By revising the number of countries and using various DEA models, it is possible to obtain different findings.

\section{References:}

1. Ali, A. I. (1994). Computational aspects of DEA. In A. Charnes, W. W. Cooper, A. Y. Lewin and L. M. Seiford (Eds.), Data envelopment analysis: Theory, methodology, and application (1st ed., pp. 63-88). New York: Springer Science+Business Media, LLC.

2. Anderson, R. I., Fok, R. \& Scott, J. (2000). Hotel industry efficiency: An advanced linear programming examination. American Business Review, 18(1), 40-48.

3. Assaf, A. G. (2012). Benchmarking the Asia Pacific tourism industry: A Bayesian combination of DEA and stochastic frontier. Tourism Management, 33(5), 1122-1127.

4. Assaf, A. G. \& Barros, C. P. (2013). A global benchmarking of the hotel industry. Tourism Economics, 19(4), 811-821.

5. Atan, M. \& Arslantürk, Y. (2015). Dünya ülkelerin turizm potansiyelinin etkinliği. Gazi Journal of Economics and Business, 1(1), 59-76.

6. Banker, R. D. \& Morey, R. C. (1986). Efficiency analysis for exogenously fixed inputs and outputs. Operations Research, 34(4), 513-521.

7. Banker, R. D., Charnes, A. \& Cooper, W. W. (1984). Some models for estimating technical and scale efficiencies in data envelopment analysis. Management Science, 30(9), 1078-1092.

8. Banker, R. D., Cooper, W. W., Seiford, L. M., Thrall, R. M. \& Zhu, J. (2004). Returns to scale in different DEA models. European Journal of Operational Research, 154(2), 345-362.

9. Barros, C. P. \& Alves, F. P. (2004). Productivity in tourism industry. International Advances in Economic Research, 10(3), 215-225.

10. Barros, C. P. \& Mascarenhas, M. J. (2005). Technical and allocative efficiency in a chain of small hotels. Hospitality Management, 24(3), 415-436.

11. Barros, C. P., Botti, L., Peypoch, N., Robinot, E., Solonandrasana, B. \& Assaf, A. G. (2011). Performance of French destinations: Tourism attraction perspectives. Tourism Management, 32(1), 141-146.

12. Bi, G., Luo, Y. \& Liang, L. (2011). Efficiency evaluation of tourism industry with data envelopment analysis (DEA): A case study in China. Journal of China Tourism Research, 7(1), 104-116. 
13. Bowlin, W. F. (1998). Measuring performance: An introduction to data envelopment analysis (DEA). The Journal of Cost Analysis, 15(2), 3-27.

14. Charnes, A., Cooper, W. W. \& Rhodes, E. (1978). Measuring the efficiency of decision making units. European Journal of Operational Research, 2(6), 429-444.

15. Charnes, A., Cooper, W. W., Lewin, A. Y. \& Seiford, L. M. (1994). Data envelopment analysis: Theory, methodology, and application. (1st ed.) New York: Springer Science+Business Media, LLC.

16. Cooper, W. W., Seiford, L. M. \& Tone, K. (2006). Introduction to data envelopment analysis and its uses: With DEA-Solver software and references. New York: Springer Science \& Business Media, Inc.

17. Cooper, W. W., Seiford, L. M. \& Tone, K. (2007). Data envelopment analysis: A comprehensive text with models, applications, references and DEA-Solver software (2nd Ed.). New York: Springer Science \& Business Media, LLC.

18. Cracolici, M. F., Nijkamp, P. \& Rietveld, P. (2008). Assessment of tourism competitiveness by analysing destination efficiency. Tourism Economics, 14(2), 325-342.

19. Despotis, D. K. \& Simirlis, Y. G. (2002). Data envelopment analysis with imprecise data. European Journal of Operational Research, 140(1), 24-36.

20. Hadad, S., Hadad, Y., Malul, M. \& Rosenboim, M. (2012). The economic efficiency of the tourism industry: A global comparison. Tourism Economics, 18(5), 931-940.

21. Hwang, S.-N. \& Chang, T.-Y. (2003). Using data envelopment analysis to measure hotel managerial efficiency change in Taiwan. Tourism Management, 24(4), 357-369.

22. Johns, N., Howcroft, B. \& Drake, L. (1997). The use of data envelopment analysis to monitor hotel productivity. Progress in Tourism and Hospitality Research, 3(2), 119-127.

23. Joppe, M. \& Li, X. P. (2016). Productivity measurement in tourism: The need for better tools. Journal of Tourism Research, 55(2), 139149.

24. Kosmaczewska, J. (2014). Tourism interest and the efficiency of its utilisation based on the example of the EU countries. Acta Scientiarum Polonorum Oeconomia, 13(1), 77-90.

25. Kulshreshtha, M. \& Parikh, J. K. (2002). Study of efficiency and productivity growth in opencast and underground coal mining in India: a DEA analysis. Energy Economics, 24(5), 439-453.

26. Oukil, A., Channouf, N. \& Al-Zaidi, A. (2016). Performance evaluation of the hotel industry in an emerging tourism destination: 
The case of Oman. Journal of Hospitality and Tourism Management, 29, 60-68.

27. Peypoch, N. (2007). On measuring tourism productivity. Asia Pacific Journal of Tourism Research, 12(3), 237-244.

28. Porter, M. E. (1990). The competitive advantage of nations. Harvard Business Review, March-April, 73-91.

29. Raab, R. L. \& Lichty, R. W. (2002). Identifying subareas that comprise a greater metropolitan area: The criterion of county relative efficiency. Journal of Regional Science, 42(3), 579-594.

30. Sherman, H. D. \& Zhu, J. (2006). Service productivity management: Improving service performance using data envelopment analysis. Boston, MA: Springer.

31. UNWTO (2016). Tourism highlights 2016 Edition.

32. Yi, T. \& Liang M. (2015). Evolutional model of tourism efficiency based on the DEA method: A case study of cities in Guangdong Province, China. Asia Pacific Journal of Tourism Research, 20(7), 789-806. 